UDC 338.516.4;339.13.012+504

DOI: 10.31651/2076-5843-2020-2-25-34

\section{SOLOKHA Dmytro}

Dr. Sc. (Economics), Professor,

Donetsk State University of Management,

Mariupol, Ukraine

ORCID ID: https://orcid.org/0000-0002-6022-1791

Solokha_D@ukr.net

\section{TANCHYK Olena}

$\mathrm{PhD}$ (Economics),

Donetsk State University of Management,

Mariupol, Ukraine

ORCID ID: https://orcid.org/0000-0002-3632-7422

tanchyk.olena@gmail.com

\section{BIELIAKOVA Oksana}

$\mathrm{PhD}$ (Economics), Associate Professor, Azov maritime institute National University

"Odesa Maritime Academy", Mariupol, Ukraine

ORCID ID: https://orcid.org/0000-0003-0363-4239

tttt66t@ukr.net

KYSIL Vitalii

Master's Degree student,

Donetsk State University of Management,

Mariupol, Ukraine

ORCID ID: https://orcid.org/0000-0001-6370-7044

v_m-71@ukr.net

\title{
THE OPTIMIZATION OF COMPETITIVE ADVANTAGES OF BUSINESS ENTITIES ACCORDING TO THE CRITERIA OF ECO-EFFICIENCY OF PRODUCTION SYSTEMS
}

The main approaches to optimizing the competitive advantages of economic entities in Ukraine in terms of implementing the main provisions of the sustainable development concept, taking into account the criterion of environmental efficiency of these processes have been considered. The criterion of eco-efficiency has been recognized as a key one both at the present stage of formation and development of the domestic market of environmentally-friendly commodities and in the long run. The dynamics and main directions of the processes of the greening the functioning of economic entities by industry have been studied. The mechanism for elaborating the strategy of economic entities development for the production and sale of environmentally-friendly commodities (provision of relevant services), a procedure and algorithm for certification of economic entities by the criterion of environmental efficiency of domestic production systems in accordance with international standards have been conceived.

Key words: competitive advantages, eco-efficiency, production system, business entity, product, environmental cleanliness, market.

Introduction. The current conditions of domestic economic entities performance are determined by large-scale and comprehensive globalization and integration processes. Global trends in the greening of production, on the one hand, and the processes of further market transformation, modernization of consumption, on the other hand, determine their divergent and contradictory impact on the stability of socio-economic systems within a single national market space.

Consolidation and expansion of the segment of commodities and services sales on the world market are possible only in case of strict compliance with environmental requirements and standards established at the global level. Thus, ensuring and maintaining competitive advantage in the long run is possible, according to the authors of the monograph [8], provided that the criterion of eco-efficiency of production systems is observed. Thereby, the chosen topic of scientific research, the main results of which are presented in this article, is of current interest and relevant.

The procedure for making strategic decisions in the field of the greening of production processes, ensuring a certain level of their environmental efficiency, as one of the key criteria determined by many factors for the competitive advantage for managers of enterprises and organizations and depends on a number of dialectically related indicators. It has to be noted that the criteria of eco-efficiency are one of the most effective levers of providing competitive advantages $[2,8]$.

Literature review. The formation of eco-efficiency of production systems is one of the most important, in our opinion, components of effective implementation of the principles of the sustainable development concept.

Conceptual bases of sustainable development management of separate business entities based on the principles of greening and eco-efficiency are presented in the works of S. Ilyashenko [5], 
O. Korintseva [4], L. Melnyk [7], L. Miroshnyk, O. Miroshnyk [ 4] O. Prokopenko [5], V. Sabadash [4], A. Sadekova [9], S. Kharichkova [11] and others.

It is worth noting a number of authors who have paid attention to the problems of market greening on the basis of improving the eco-efficiency of production systems $[1 ; 2 ; 6 ; 8 ; 10]$. However, the dynamic changes in the market environment need to study these processes in terms of optimizing competitive advantages namely, the environmental efficiency criterion.

However, the importance to take into account national and sectoral approaches to the system of market participants development requires further study of the systemic greening of production, ensuring its environmental efficiency, further organization and development of the market of environmentallyfriendly commodities (EFC) on the principles of its components interaction.

The purpose of the article is to study the main theoretical and methodological approaches and formulate practical recommendations for optimizing the competitive advantages of Ukrainian businesses in the market of environmentally-friendly commodities (internal and external) by the criterion of ecoefficiency of production systems.

Results and discussion. Identifying key conditions for stable operation of the production system on the basis of legal, environmental and technical and economic criteria is usually difficult, as optimization of one of the above parameters may be unacceptable due to imperfections in the price system and calculation methods shortage of raw materials and energy, specifics of the economic mechanism of settlements between suppliers and commodities consumers, as well as other reasons independent of economic entities [8].

Environmentally hazardous production systems are characterized by the fact that they are of high risk. Obtaining and producing quality products in such systems become problematic and uncertain and unstable. In these systems, the relevant productions, which are characterized by significant material, financial and other costs, are described by high accident rate and low environmental safety. All this limits the use of traditional decision-making methods based on the principles of reasonable sufficiency and in fact encourages managers and service personnel to perform work with a minimum failure probability.

A significant disadvantage of traditional indicators for measuring the efficiency of production processes is that they do not take into account the environmental and resource effects of production. The need to take into consideration the environmental factors in the decisions made by economic entities and in a comprehensive assessment of their effectiveness is reflected in the concept of eco-efficiency (EcoEf), according to which the authors offer its calculation as follows:

$$
E c o E f=\frac{V A}{P R},
$$

where EcoEf - eco-efficiency of production systems;

$V A$ - value added;

$P R-$ pollution and resources added.

It is necessary to consider possible economic and mathematical models for optimizing the range of enterprises on the criterion of eco-efficiency. It is important to enter variables and have the following: xiec - the number of units of the $i$-th EFC;

$x i$ - the number of units of the i-th product that do not belong to the EFC market;

It is necessary to consider: market;

rji-the amount of $j$-th resource required to produce a unit of $i$-th product that does not belong to the EFC

rjie - the amount of resource $j$-th type required for the production of the unit of the $i$-th environmentallyfriendly commodities;

$n$ - the number of commodities produced at the enterprise;

nec-the number of environmentally-friendly commodities produced at the enterprise;

$n$-number of resources:

$i$-type of commodities;

$j$-type of resource;

piec - profit brought by the unit of the i-th EFC;

bpiec - damage caused by the unit of the i-th EFC; 
pi-profit by a unit of the $i$-th product that does not belong to the EFC market;

bpi-contingent damage caused by a unit of the i-th EFC that does not belong to the EFC market;

Lgrieк - the lower limit of production of the $i$-th EFC;

Ugriek - the upper limit of production of the $i$-th EFC;

Lgri-the lower limit of production of the $i$-th product that does not belong to the EFC market;

Ugri - the upper limit of production of the i-th product that does not belong to the EFC market;

$R j$-resources of the j-th type, which enterprises have.

Given the notation entered, one can set restrictions:

$$
\begin{aligned}
& L g r_{\text {iек }} \leq x_{\text {iек }} \leq U g r_{\text {iек }} \quad i=1,2, \ldots m_{\text {ек }}
\end{aligned}
$$

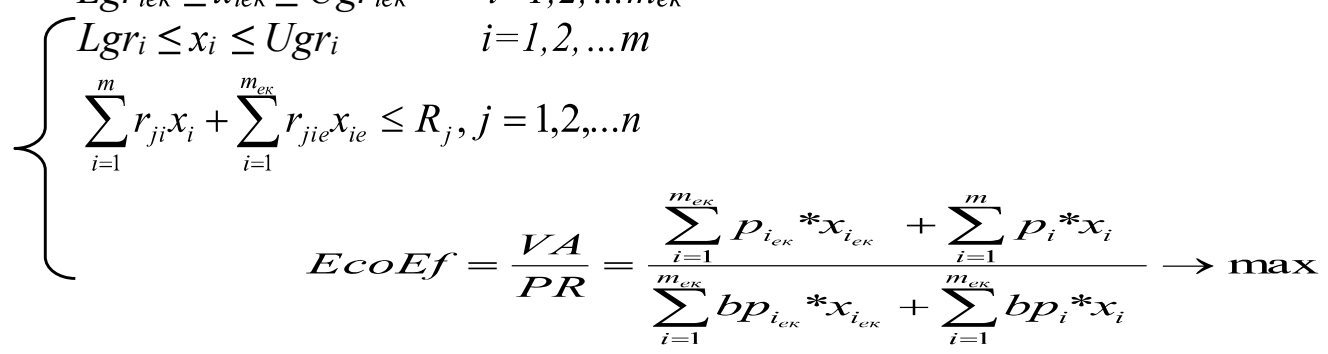

Constraints (2) and (3) set the limits of variables change. Constraint (4) sets restrictions on resource sharing. The criterion of eco-efficiency is used as an objective function.

For instance, for the enterprise of JSC "Vasylkivsky Refrigerators Plant" certain types of refrigerators can be considered as commodities. Resource constraints are related to raw materials and lack of funding [2].

According to the author's approach, the formal conditions of market perception of environmental innovations can be written as follows:

1. $\mathrm{Coc}-\mathrm{Cei}>0 ; \mathrm{Bip},>0$.

2. $\mathrm{Coc}-\mathrm{Cei}>0 ; A s>0$.

3. $\mathrm{Coc}-\mathrm{Cei}<0 ; \mathrm{Bip}-(\mathrm{Cei}-\mathrm{Coc})>0$.

4. $\mathrm{Coc}-\mathrm{Cei}<0 ; \mathrm{As}>0$. Bip $>(\mathrm{Coc}-\mathrm{Cei})+\mathrm{Cei} .>0$.

where Coc - the cost of consumption of ordinary commodities;

Cei - the cost of consuming environmental innovations;

Ciei - the cost of state (regional) incentives for environmental innovation;

Bip - the advantages of an innovative product, significant for the consumer;

As - socially significant advantages of the innovative goods.

The proposed dependencies (1) allow formal procedures to assess the market prospects of environmental innovations as the most important element of the EFC market and the adequacy of individual consumer preferences, reasonably plan costs $(\mathrm{Coc})$ for state or regional stimulation of production and consumption of socially significant environmental innovations.

Producers of eco-innovation have to take into account the impact of environmental pressure and environmental involvement factors when assessing their chances of market success. In particular, such as legal restrictions, requirements of national and international standards, cost-effectiveness, environmentally oriented public actions, environmental awareness of society and etc.

However, there are radical environmental innovations that have no direct analogues. For this type of innovation (including environmental) according to [3;10] it is recommended while analyzing demand and assessing market prospects to take into consideration the following factors: critical level of consumer capital, critical assignation of commodities, critical minimum income, critical level of risk, critical amount of consumer free time. The speed of overcoming these barriers affects the time required to introduce eco-innovation to the market, the initial stage of the demand formation and sales growth.

Taking the foregoing into consideration, in the authors' opinion, the formal conditions for the market's perception of radical environmental innovations are as follows: 


$$
\begin{aligned}
& N_{c} \geq C_{c}^{c r}, \\
& L_{c a} \geq L_{c a}^{c r}, \\
& L_{c i} \geq L_{c i}^{c r}, \\
& L_{c r} \geq L_{c r}^{c r}, \\
& A_{c t} \geq A_{c t}^{c r},
\end{aligned}
$$

Nc, Lcs, Lci, Lcr, Act - actual values, respectively: number of consumers (consumer capital), level of commodities suitability, level of consumer income, level of consumer risk, amount of consumer free time;

$N c^{c r}, L_{c a}{ }^{c r}, L_{c i}{ }^{c r}, L c r^{c r}, A c t^{c r}$ - critical values, respectively: the number of consumers (consumer capital), the level of assignation of commodities, the level of consumer income, the level of consumer risk, amount of consumer free time.

The obtained results make the theoretical and methodological basis more profound for assessing the sufficiency of the EFC market potential for the perception of environmental innovations; allow planning activities for regional or state support, as well as increasing the degree of validity and chances for environmentally-oriented innovation projects to be successfully implemented.

For the formation of the domestic market of environmentally-friendly commodities, it is necessary to create an adapted regulatory framework to stimulate producers, creating a competitive environment. In the diagram of Figure 1, the authors present the mechanism for elaborating the strategy for the economic entities development of EFCs production.

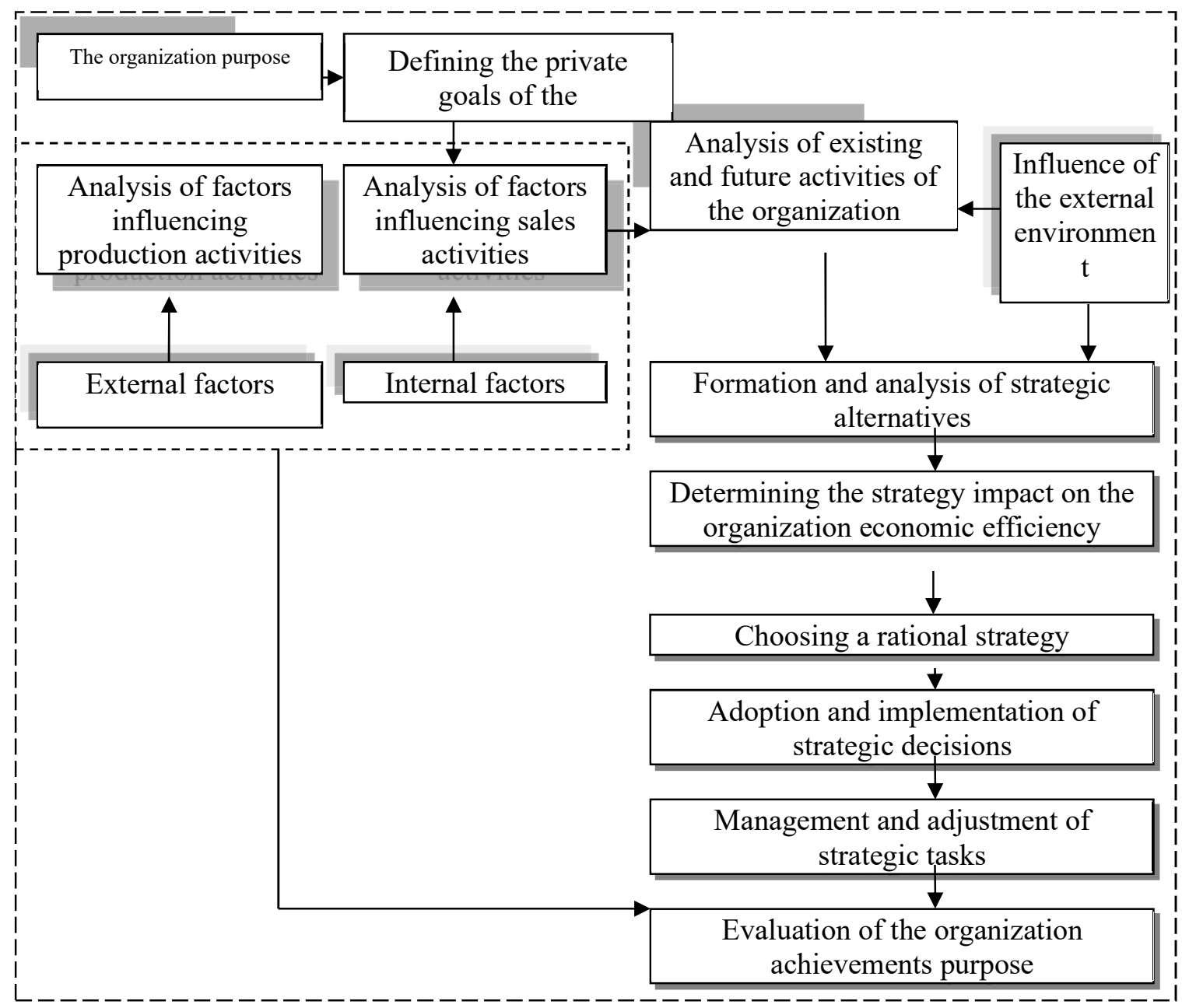

Fig. 1. The mechanism for eleborating the strategy for the economic entities development for the production and sale of environmentally-friendly commodities

Source: developed by the authors 
The strategy, in this case, is presented as a generalized model of actions necessary to achieve the goal. Influences of strategic character have to be carried out according to a certain algorithm, which is a logical sequence. In relation to market participants, the development strategy of the production organization and sale of EFCs is based on the assessment of strategic alternatives, taking into account the influence of external factors. It is necessary at the legislative level (based on the experience of other countries) to prepare and thus protect its own consumer and producer from spontaneous market penetration of environmentally hazardous products (GMS).

As a positive example, Ukraine is actively pursuing measures to implement international environmental standards in order to prepare Ukrainian enterprises for the strict rules of international trade, realizing that the presence of a certified environmental management system can become an integral part of Ukraine's strategic partners to purchase Ukrainian goods. Derzhkomstat of Ukraine was the first among the CIS countries to prepare for direct implementation the international standards ISO 14001, 14004, 14010, 14011, 14012 which establish general rules of environmental management, principles and procedures of environmental audit and standardized criteria for environmental auditors.

However, these regulations are voluntary. It is essential to note that the environmental management system is not sufficiently implemented in domestic enterprises. From this point of view, domestic producers can hardly be considered competitive in the world market. Ukraine must consciously and preparedly integrate into the world community. To this end, a package of documents has to be developed and adopted at the state level, which ensures further harmonious (taking into account environmental and economic factors) integration of Ukraine into the WTO and promoting the attraction of environmentally-oriented international investments into the country's economy.

The authors considered the process of formation and development of the market of ecological commodities in the context of the general greening of production. This allowed moving to the dynamic characteristics of the development process and summarizing their results in table 1.

Table 1

Dynamics of characteristics of the greening process of production systems

\begin{tabular}{|c|c|c|c|c|}
\hline $\begin{array}{c}\text { Process } \\
\text { characteristics }\end{array}$ & $\begin{array}{c}\text { Changing } \\
\text { characteristics over } \\
\text { time }\end{array}$ & The past situation & $\begin{array}{l}\text { The current } \\
\text { situation }\end{array}$ & $\begin{array}{l}\text { The future } \\
\text { situation }\end{array}$ \\
\hline \multirow[t]{3}{*}{$\begin{array}{l}\text { Management } \\
\text { tools }\end{array}$} & $\begin{array}{c}\text { Local market } \\
\text { management tools }\end{array}$ & Corporate rules & $\begin{array}{l}\text { Decision-making } \\
\text { rules, the concept of } \\
\text { environmental } \\
\text { management }\end{array}$ & $\begin{array}{l}\text { Fighting the } \\
\text { effects of } \\
\text { pollution }\end{array}$ \\
\hline & $\begin{array}{c}\text { Market management } \\
\text { tools }\end{array}$ & $\begin{array}{c}\text { Environmental } \\
\text { legislation }\end{array}$ & $\begin{array}{c}\text { Underestimation of } \\
\text { the role of the } \\
\text { greening }\end{array}$ & $\begin{array}{l}\text { Forecasting the } \\
\text { processes of the } \\
\text { greening } \\
\text { development }\end{array}$ \\
\hline & $\begin{array}{l}\text { Markets management } \\
\text { tools }\end{array}$ & $\begin{array}{l}\text { International } \\
\text { agreements, norms } \\
\text { and standards }\end{array}$ & $\begin{array}{l}\text { Solutions to current } \\
\text { environmental } \\
\text { problems }\end{array}$ & $\begin{array}{l}\text { Pollution } \\
\text { prevention }\end{array}$ \\
\hline Stakeholders & $\begin{array}{c}\text { Individuals, firms are } \\
\text { sometimes local } \\
\text { authorities }\end{array}$ & $\begin{array}{l}\text { Authorities. Non- } \\
\text { governmental } \\
\text { organizations }\end{array}$ & $\begin{array}{l}\text { Consumers and } \\
\text { individuals. } \\
\text { International } \\
\text { organizations }\end{array}$ & $\begin{array}{l}\text { Public authorities. } \\
\text { Non-governmental } \\
\text { and other public } \\
\text { organizations, } \\
\text { consumers, } \\
\text { investors }\end{array}$ \\
\hline $\begin{array}{l}\text { Possible } \\
\text { consequences }\end{array}$ & $\begin{array}{l}\text { Local pollution, } \\
\text { depletion of natural } \\
\text { resources }\end{array}$ & $\begin{array}{l}\text { Regional, national } \\
\text { environmental } \\
\text { problems }\end{array}$ & $\begin{array}{c}\text { Global national and } \\
\text { regional } \\
\text { environmental } \\
\text { problems }\end{array}$ & \\
\hline
\end{tabular}

Source: developed by the authors.

From the point of view of the ecological business development, the formation of the market of ecological goods, works and services, it is important to consider the specificity of the economy branch. 
It is known that any production is the biggest polluter of the environment and consumer of the main part of natural resources. Therefore, historically, the first steps in the greening of development were taken, namely, wastewater treatment, control of industrial waste and emissions into the atmosphere, energy and resource conservation measures, and later - the introduction of low-waste and free-waste technologies and others. In Table 2, based on materials [7], the authors show the directions of the process of greening the economy by individual industries on the example of trade and services.

One of the main directions of the greening of production is the restoration and modernization of fixed assets of enterprises, reducing the degree of their negative impact on the environment. This is especially of current interest for Ukraine, where the operation of equipment, including treatment, in the basic industries and transport sector reaches $70-80 \%$.

The main obstacle to the development of the ecological commodities market in Ukraine is weak legal regulation, including the lack of a legally established concept of ecological commodities, as well as a system of technical regulations and national standards for the greening of agriculture and production of ecological commodities.

Table 2

The main directions of the processes of the greening the functioning of business entities on a sectoral basis

\begin{tabular}{|c|c|}
\hline Industry & The main directions of greening \\
\hline Utilities system & $\begin{array}{l}\text {-modernization of existing and introduction of new types of fixed assets, types of raw } \\
\text { materials, heat supply technologies, energy and other types of utilities; -radical } \\
\text { restructuring of the processes of collection and utilization of household waste; } \\
\text {-implementation of more architectural and planning decisions in urban construction; } \\
\text { - control over noise sources, electromagnetic and radiation, vibration, etc. }\end{array}$ \\
\hline Trade & $\begin{array}{l}\text { - Introduction of environmentally-friendly and safe types of packaging; } \\
\text { - Improving architectural and planning decisions when placing trade objects. }\end{array}$ \\
\hline $\begin{array}{l}\text { Recreational } \\
\text { complex }\end{array}$ & $\begin{array}{l}\text { - Improvement and modernization of existing health resorts and rest homes; } \\
\text { - Expansion of the network of recreational facilities, prevention of "overload" of nature; } \\
\text { - Introduction of the most environmentally-friendly methods of combating } \\
\text { environmental pollution in recreational areas; } \\
\text { - Administrative and economic measures to reduce economic activity and construction } \\
\text { in recreational areas. }\end{array}$ \\
\hline
\end{tabular}

Source: developed by the authors

In this regard, the environmentally-friendly commodities certification procedure has been proposed. Based on foreign and domestic experience, the procedure for product certification in the technological chain (Fig. 2) may include the following elements.

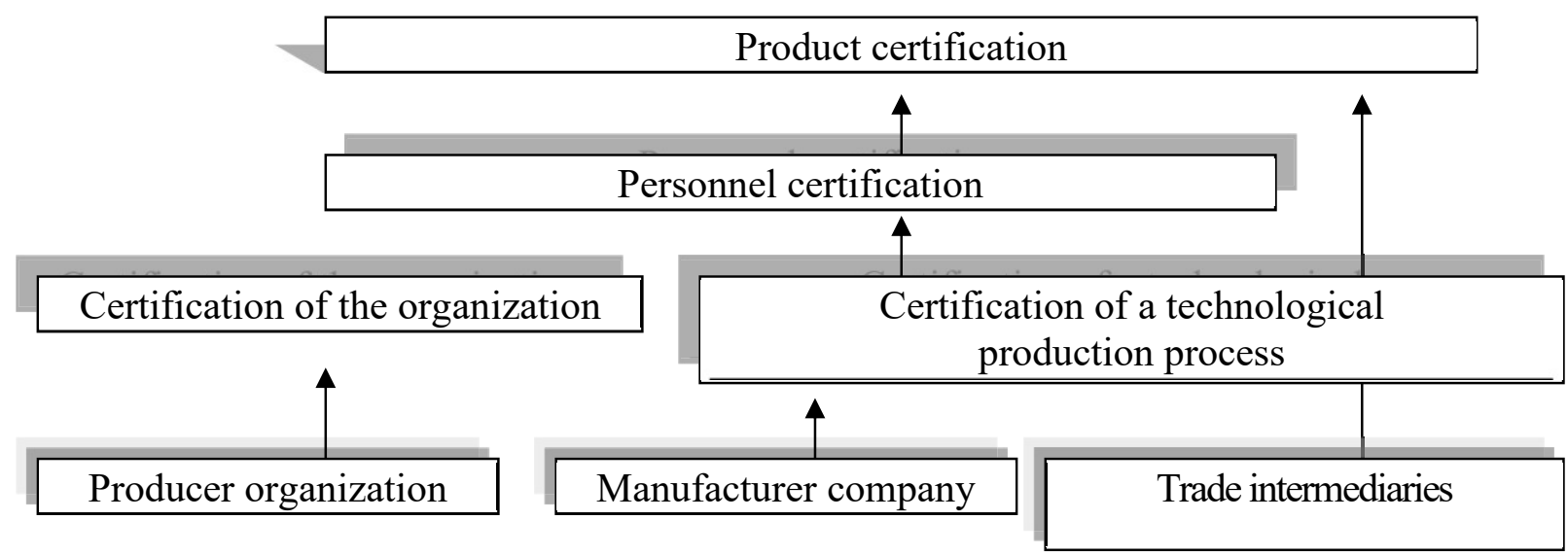

Fig. 2. Procedure for certification of business entities by the criterion of eco-efficiency of production systems

Source: developed by authors

According to the proposed procedure for business entities certification (Fig. 2) by the criterion of eco-efficiency of production systems, the authors propose the algorithm for this process (Fig. 3). 


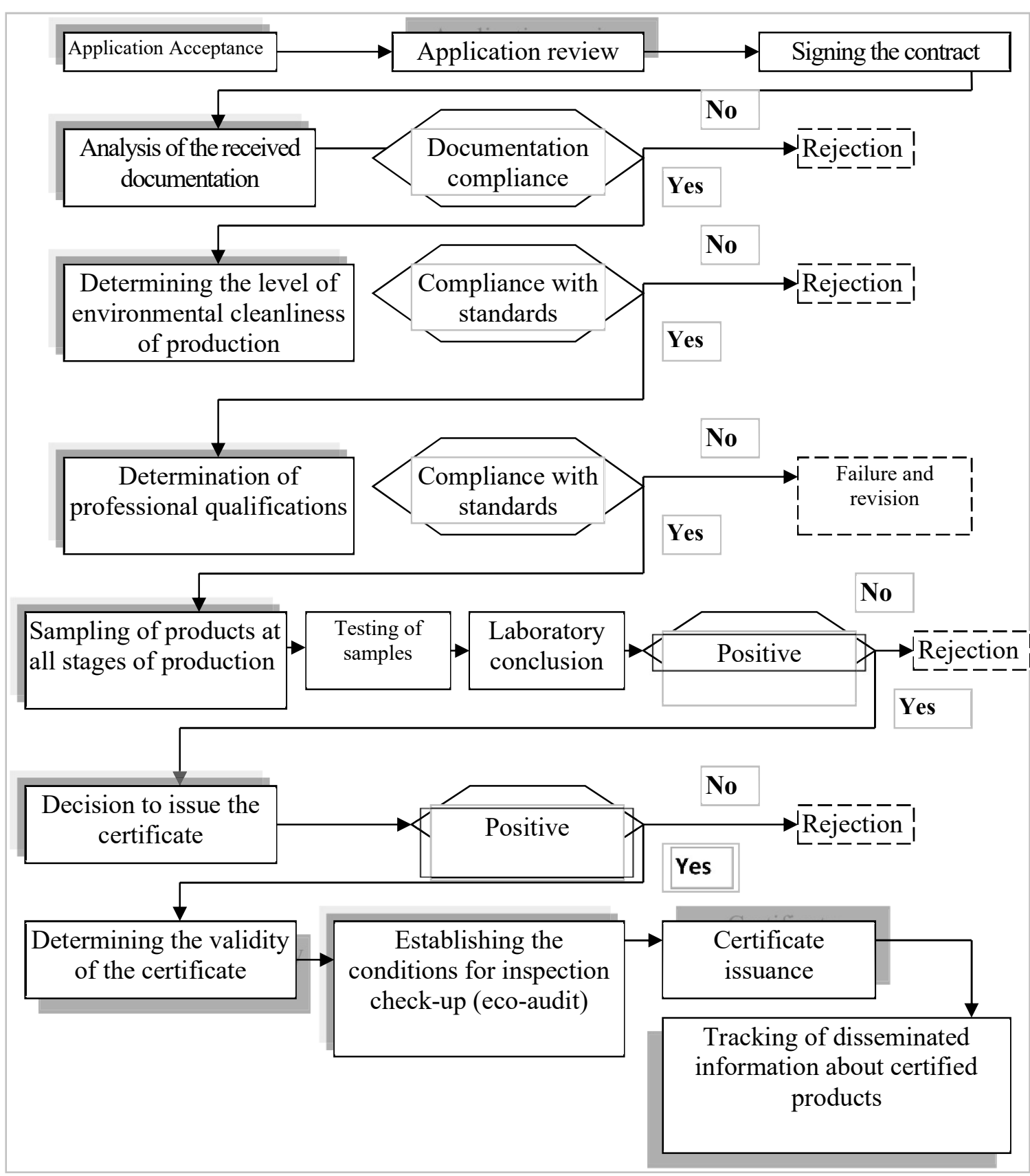

Fig. 3. Algorithm for business entities certification by the criterion of the production systems efficiency

Source: developed by authors

Due to the exacerbation of environmental problems in the world economy, certification of products for compliance with international environmental standards is becoming increasingly important. Exports from countries with effective environmental policies tend to grow rapidly. The world market of environmentally-friendly commodities is being formed and actively developing.

International organizations are still developing a single international classification of this market and common criteria for the concept of "environmentally friendly goods". However, the influence of environmental factors on competition, on international trade development and export production is becoming one of the dominants of the XXI century.

Countries with the strictest environmental standards are also the most competitive ones. Therefore, the World Industrial Conference on Environmental Management and the Council of Entrepreneurs for Sustainable Development, which takes into account the environmental component, were originated. For their members (initially, the Council included 50 leading companies from developed countries) they set higher environmental standards [8]. 
Certification allows getting complete and accurate information about the production of EFC at all stages, gives consumers a guarantee of compliance with norms and standards that confirm the environmental friendliness of the product. There are already many multilateral and bilateral international agreements and treaties on environmental security. Thus, the WTO Committee on Trade and Environment establishes the relationship between the principles and objectives of trade policy of individual countries and the provisions of international treaties and agreements on environmental protection. In the conditions of economic globalization processes and aggravation of competition in the domestic and world commodity markets the competitiveness of production is in many respects defined by its ecological parameters: the degree of conformity to the international ecological standards and use of safe production technologies, ecological expenses, level of ecological management and audit, obligations that comply with the international agreements on environmental protection.

In accordance with the requirements of ISO and WTO on the basis of "implemented technical regulations" the environmental rating of Ukrainian products may change. At least the attitude of entrepreneurs and agencies to the definition of environmental costs and reporting on environmental investments and operating costs (including the treatment of industrial waste) has to be adjusted. In this regard, special attention is to be paid to improving the system of environmental certification, increasing the number of national organizations certified for compliance with international environmental standards ISO - 14001 and "Eco-management and Audit Scheme EU".

Unlike international environmental management standards (ISO 14000, EMAS), which are management-oriented systems, the environmental marketing system focused on long-term profitability and belongs to the problem-oriented type, aimed primarily at justifying and selecting the most effective possible solutions to improve the situation of domestic production competitiveness.

The focus of this model is specific preventive marketing measures and priorities developed taking into account the study of the specifics of consumer preferences, by adjusting decisions on the elements of the marketing complex, as well as relevant investment projects aimed at improving environmental cleanliness and product safety.

The combination of these measures, as a rule, forms in contrast to the reactive, "adaptive" marketing strategy the proactive strategy to address the problems of production system profitability, penetration of foreign markets, and brand and manufacturer image in the partner marketing system.

Conclusions. Objectively complex identification of the needs of the main consumer groups is gradually forming the basis for the functioning of the EFC market. However, the diagnostic approach to its formation has to be used in combination with the optimization approach, which is implemented through the formation and implementation of appropriate strategies, development of the legal framework, structure and infrastructure of the market.

Business entities are the direct bearers of special economic interests, the implementation of which is associated with the processes of production and sale of environmentally-friendly commodities, as a basis for optimizing competitive advantages. The high requirements for the quality of environmentallyfriendly commodities make it necessary to create and operate a system of certification of production systems and infrastructure in general.

The system of optimization of competitive advantages in the field of production and marketing of EFC (provision of relevant services) ought to be focused on planning and implementation of changes, the revival of innovation processes due to the dynamics of the advantages of end-users of products (services). The practical implementation of these conclusions and relevant recommendations will create the conditions necessary for the accelerated formation and development of the domestic EFC market. The further research ought to focus on the development and testing of a multivariate economicmathematical model for the calculation of existing and expected indicators of eco-efficiency of production systems in order to optimize competitive advantages.

\section{References (in language original)}

1. Барабашова Н., Висоцький Д. Інновації як фактор забезпечення екологічної безпеки промислово розвинутого регіону. Підприємництво, господарство, право. 2012. С. 74-87.

2. Белякова О.В. Оптимизация конкурентных преимуществ предприятий по критерию экоэффективности производственных систем. Зб. наук. статей «Управління розвитком». № 9. Харків : Вид-во XНEУ, 2008. C. 94-108. 
3. Божкова В.В. Особливості факторної оцінки екологічних ризиків інноваційних проектів. Економіка : проблеми теорії та практики. Дніпропетровськ : ДНУ, 2001. Вип. 117. С. 184-198.

4. Мірошник Л.Г., Сабадаш В.В., Мірошник О.I., Корінцева О.І. Економічний механізм екологізації суспільного виробництва. Проблеми сталого розвитку України. К.: БМТ, 1998. С. 106-118.

5. Ілляшенко С.М., Прокопенко О.В. Формування ринку екологічних інновацій: економічні основи управління: [монографія]. Суми : ВТД «Університетська книга», 2002. 250 с.

6. Кислый В., Лапин Е., Трофименко Н. Экологизация управления предприятием: [монография]. Сумы : ИТД «Университетская книга», 2002. 232 с.

7. Мельник Л.Г, Сабадаш В.В., Мельник О.І., Корінцева О.І. Економічний механізм екологізації суспільного виробництва. Проблеми сталого розвитку України. К. : БМТ, 1998. С. 106-118.

8. Должанський І.З., Бєлякова О.В. Організація процесу формування та розвитку ринку екологічно чистих товарів. Монографія. Донецьк: ДонНУЕТ, Купріянов В.С., 2009. 235 с.

9. Садеков А.А. Механизм эколого-экономического управления предприятием: [монография]. Харьков : Издательский Дом «ИНЖЭК», 2004. 224 с.

10. Шипуліна Ю.С. Теоретико методичні підходи до оцінки достатності ринкового потенціалу для сприйняття нової продукції (на прикладі екологічних товарів). Механізм регулювання економіки, економіка природокористування, економіка підприємства та організачія виробництва. 2004. № 1. С. 44-49.

11. Харічков С.Н. Проблеми інвестування виробництва екологічно чистих продуктів. Вісник Сумського державного аграрного університету. Серія «Економіка та менеджмент». Вип. 1. 2001. С. $204-207$.

\section{References}

1. Barabashova N., Vysotsky D. (2012). Innovations as a factor in ensuring the environmental safety of the industrialized region. Entrepreneurship, economy, law, 74-87.

2. Belyakova O. (2008). Optimization of competitive advantages of enterprises according to the criterion of ecoefficiency of production systems. Collection of scientific articles "Development Management", 9, 94-108.

3. Bozhkova V. (2001). Peculiarities of factor assessment of ecological risks of innovative projects. Economics: problems of theory and practice, 117, 184-198.

4. Miroshnyk L., Sabadash V., Miroshnyk O., Korintseva O. (1998). Economic mechanism of the greening of social production. Problems of sustainable development of Ukraine. K.: BMT, 106-118. (in Ukr.).

5. Ilyashenko S., Prokopenko O. (2002). Formation of the market of ecological innovations: economic bases of management: [monograph]. Sumy: VTD "University Book", 250 p. (in Ukr.).

6. Kisly V., Lapin E., Trofimenko N. (2002). Ecology of enterprise management: [monograph]. Sumy: ITD "University Book", 232 p. (in Ukr.).

7. Melnyk L., Sabadash B., Melnyk O., Korintseva O. (1998). Economic mechanism of greening of social production. Problems of sustainable development of Ukraine. K.: BMT, 106-118. (in Ukr.).

8. Dolzhansky I., Beliakova O. (2009). Organization of the process of formation and development of the market of environmentally-friendly goods. Monograph. Donetsk: [DonNUET], Kupriyanov V, 235 p. (in Ukr.).

9. Sadekov A. (2004). The mechanism of environmental and economic enterprise management: [monograph]. Kharkiv: Publishing House "INZHEK", 224 p. (in Ukr.).

10. Shipulina Yu. (2004). Theoretical and methodological approaches to assessing the adequacy of market potential for the perception of new products (on the example of environmental products). Mechanism of economic regulation, economics of nature, business economics and organization of production, 1, 44-49.

11. Kharichkov S. (2001). Problems of investing in the production of environmentally-friendly products. Bulletin of Sumy State Agrarian University. Economics and Management Series, 1, 204-207.

\author{
СОЛОХА Дмитро Володимирович \\ д.е.н, професор, \\ декан факультету економіки, \\ Донецький державний університет управління, \\ м. Маріуполь, Україна
}

\section{ТАНЧИК Олена Ігорівна}

к.е.н., завідувач кафедри іноземних мов, Донецький державний університет управління, м. Маріуполь, Україна

\begin{abstract}
БЄЛЯКОВА Оксана Володимирівна
к.е.н., доцент, доцент кафедри менеджменту і підприємництва на морському транспорті, Азовський морський інститут Національного університету «Одеська морська академія», м. Маріуполь, Україна
\end{abstract}

\section{КИСІЛЬ Віталій Володимирович}

магістрант кафедри екологічного менеджменту, Донецький державний університет управління, м. Маріуполь, Україна

\section{ОПТИМІЗАЦІЯ КОНКУРЕНТНИХ ПЕРЕВАГ СУБ'СКТІВ ГОСПОДАРЮВАННЯ ЗА КРИТЕРІЕМ ЕКОЕФЕКТИВНОСТІ ВИРОБНИЧИХ СИСТЕМ}

Проблема. Сучасні умови функціонування вітчизняних суб'єктів господарювання визначаються досить масштабними ци всеохоплюючими глобалізачійно-інтеграційними процесами. Загальносвітові тенденції екологізачії сфери виробництва, з одного боку, і прочеси подальшої ринкової трансформачї, модернізачії 
сфери споживання, з іншого, детермінують їх різноспрямований ци суперечливий вплив на стабільність розвитку сочіально-економічних систем у рамках єдиного начіонального ринкового простору. Закріплення й розширення сегменту реалізації товарів й послуг на світовому ринку можливо лише за умов жорсткого дотримання екологічних вимог й стандартів, що закріпилися на глобальному рівні, отже, забезпечення й утримання конкурентних переваг в довгостроковій перспективі можливе за умов бездоганного дотримання критерію екоефективності виробничих систем. Таким чином, обрана тема наукового дослідження, основні результати якого представлені в даній статті, є чілком своєчасною й актуальною. Прочедура прийняття стратегічних рішень у сфері екологізачії виробничих прочесів, забезпечення певного рівня їх екоефективності як одного з ключових критеріїв забезпечення конкурентних переваг керівниками підприємств $і$ організацій визначається багатьма факторами й залежить від чілого ряду діалектично пов 'язаних показників, однак далі скончентроване дослідження саме на критерії екоефективності, як одного з найбільш дієвих важелів забезпечення конкурентних переваг.

Мета. Дослідити основні теоретико-методологічні підходи и сформулювати практичні рекомендачіі щодо оптимізачії конкурентних переваг суб'єктів господарювання України на ринку екологічно чистих товарів (внутрішньому й зовнішньому) за критерієм екоефективності функціонування виробничих систем.

Результати. Досліджено стан й перспективи реалізації основних засад конщепції сталого розвитку в Україні. Встановлено, щуо одним з системо утворюючих критерїв забезпечення ефективного функціонування суб' сктів господарювання в довгостроковій перспективі є критерій екоефективності. Розглянуто основні підходи щодо оптимізації конкурентних переваг суб'єктів господарювання України в умовах реалізаціі основних положень конщепчіі сталого розвитку з урахуванням критерію екоефективності зазначених прочесів, представлено основні економіко-математичні залежності зазначених економічних явищ. Критерій екоефективності визнано як ключовий як на сучасному етапі формування й розвитку вітчизняного ринку екологічно чистих товарів, так й в довгостроковій пролонгованій перспективі. Досліджено динаміку й основні напрямки прочесів екологізаџії функиіонування суб'єктів господарювання за галузевою ознакою (виробничтво матеріальних благ, надання послуг, організація торгівельного бізнесу). Запропоновано механізм розробки стратегї̈ розвитку суб 'єктів господарювання з виробництва й збуту екологічно чистих товарів (надання відповідних послуг), прочедуру й алгоритм сертифікачї суб'єктів господарювання за критерісм екоефективності вітчизняних виробничих систем відповідно до світових стандартів.

Наукова новизна. Набуло подальшого розвитку пропозииї щуодо оптимізації конкурентних переваг вітчизняних суб'сктів господарювання за критерісм екоефективності виробничих систем в умовах

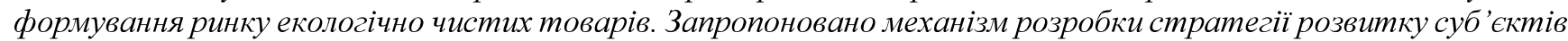
господарювання з виробництва й збуту екологічно чистих товарів (надання відповідних послуг), прочуедуру й алгоритм сертифікачії суб'єктів господарювання за критерієм екоефективності вітчизняних виробничих систем відповідно до світових стандартів.

Висновки. Об'єктивно складна ідентифікачія потреб основних груп споживачів поступово формує основу для функціонування ринку ЕЧТ. Однак діагностичний підхід до його формування необхідно використовувати в комплексі з оптимізачиійним підходом, щяо реалізується шляхом формування й реалізачії відповідної стратегії, розвитком законодавчої бази, структури й інфраструктури ринку. Суб'єкти господарювання є безпосередніми носіями особливих економічних інтересів, реалізачія яких пов'язана 3 прочесами виробничтва й реалізачії екологічно чистої продукиії як основи оптимізачії конкурентних переваг. Високі вимоги, шо пред'являють покупиі до якості екологічно чистої продукції, обумовлюють необхідність створення й функціонування системи сертифікації виробничих систем й інфраструктури в иілому. Систему оптимізачії конкурентних переваг у сфері виробниитва й збуту ЕЧТ (надання відповідних послуг) необхідно орієнтувати на планування й реалізачію змін, пожвавлення інновауійних прочесів, обумовлених динамікою переваг кінчевих споживачів продукиї (послуг). Практична реалізачія чих висновків і відповідних рекомендачій дозволить створити умови, необхідні для прискореного формування й розвитку вітчизняного ринку ЕЧТ. Подальші дослідження слід скончентрувати на побудові й апробачї мультиваріантної економікоматематичної моделі, щяодо розрахунку наявних й очікуваних показників екоефективності виробничих систем задля оптимізачії конкурентних переваг.

Ключові слова: конкурентні переваги, екоефективність, виробнича система, суб'єкт господарювання, товар, екологічна чистота, ринок.

Одержано редакиією: 07.03.2020 Прийнято до публікаиії: 18.05.2020 